Article

\title{
Modeling Short-Term Landscape Modification and Sedimentary Budget Induced by Dam Removal: Insights from LEM Application
}

\author{
Dario Gioia ${ }^{1, *(1)}$ and Marcello Schiattarella ${ }^{2}$ (i) \\ 1 Istituto di Scienze del Patrimonio Culturale (ISPC), Consiglio Nazionale delle Ricerche, Tito Scalo, \\ I-85050 Potenza, Italy \\ 2 Dipartimento delle Culture Europee e del Mediterraneo (DiCEM), Università degli Studi della Basilicata, \\ I-75100 Matera, Italy; marcello.schiattarella@unibas.it \\ * Correspondence: dario.gioia@cnr.it; Tel.: +39-0971-427309
}

Received: 3 October 2020; Accepted: 27 October 2020; Published: 30 October 2020

\begin{abstract}
Simulation scenarios of sediment flux variation and topographic changes due to dam removal have been investigated in a reservoir catchment of the axial zone of southern Italy through the application of a landscape evolution model (i.e.,: the Caesar-Lisflood landscape evolution models, LEM). LEM simulation highlights that the abrupt change in base level due to dam removal induces a significant increase in erosion ability of main channels and a strong incision of the reservoir infill. Analysis of the sediment dynamics resulting from the dam removal highlights a significant increase of the total eroded volumes in the post dam scenario of a factor higher than 4 . Model results also predict a strong modification of the longitudinal profile of main channels, which promoted fluvial incision upstream and downstream of the former reservoir area. Such a geomorphic response is in agreement with previous analysis of the fluvial system short-term response induced by base-level lowering, thus demonstrating the reliability of LEM-based analysis for solving open problems in applied geomorphology such as perturbations and short-term landscape modification natural processes or human impact.
\end{abstract}

Keywords: landscape evolution; soil erosion; DEM analysis; applied geomorphology; dam removal; base-level lowering; southern Italy

\section{Introduction}

Base-level variation has a significant impact on a geomorphological system with severe changes in channel incision rate, sediment flux, and spatial distribution of geomorphological processes [1-3]. A fast transition from endorheic (i.e.: centripetal drainage or closed basin) to exorheic drainage is one of the most relevant cases of disequilibrium of a landscape, because it promotes a non-linear response of the fluvial systems and a complex spatial and temporal response of river incision and sediment flux (see for example [4]). Several works have investigated the long-term response of the drainage network to a transition from endorheic to exorheic conditions due to complex climateor tectonic-driven processes such as sediment overfilling, headward stream erosion, and threshold incision or fluvial capture [5-8]. This kind of analysis is largely based on morphotectonic studies and related qualitative reconstruction of past stages of landscape evolution [9-11]. Dam construction and/or removal is one of the human-induced perturbations of the fluvial net with a stronger impact on the geomorphic system [12-14]. Many works have been focused on the analysis of the effects of this kind of disturbance on the fluvial network and sediment flux, highlighting a typical response that is strongly controlled by the post-dam river longitudinal profile. In fact, upstream knickpoint 
retreat generally promoted incision of both upland areas and reservoir infill, but several works have demonstrated that local factors such as rates of knickpoint migration [15,16], bedrock erodibility [17,18], grain-size and texture of reservoir sediment [19] and width of the reservoir [17,19] can drive a complex response of river processes and promote a high spatial and temporal variability of erosion and deposition. Most of these studies are based on field and remote sensing data at limited spatial and temporal scales $[17,19,20]$ or on the application of 1-D models [21,22]. For example, extensive geomorphic analyses of dam removal scenarios have been conducted in the USA through: (i) the direct measurements of the post-dam modification of morpho-sedimentary features supported by one-dimensional hydrodynamic modeling [17]; or (ii) the application of channel evolution models such as CONCEPTS and DREAM [21,22]. Such models have a significant limitation that they are not able to fully capture the spatial (i.e., lateral) distribution of river processes, channel modification, and sediment flux.

In the last years, landscape evolution models (LEMs) have been extensively used to simulate short- and long-term geomorphic scenarios of sediment flux and topographic modification in different natural environments [23-27]. These studies have demonstrated that LEMs represent a powerful tool to predict morpho-sedimentary adjustments related to changes in land use, climate setting, and base levels [24,28-31]. Recently, the Caesar-Lisflood LEM was used to investigate the short-term (i.e., at a decadal scale) pattern and rates of geomorphic changes and associated sediment flux induced by removal of multiple dams in the middle reach of Kaja River, Austria [32]. The authors demonstrated the usefulness of the LEM to predict the 2-D geomorphological and sedimentary effect of the abrupt base-level fall related to dam removal. This kind of investigation overcomes the clear limitation of 1-D or empirical models and can provide a significant opportunity to modify different controlling factors such as climate setting, land use, vegetation growth, and sediment features. The main limitation of the application of such models is that a reliable calibration of a LEM is really complicated and several well-known reasons such as the difficulty of both the selection of model parameters and the absence of extensive validation of the prediction ability of the model results in natural environments could represent a significant limitation in its application in complex natural landscapes [25,33]. Thus, a test area where a LEM is already calibrated can provide a reliable opportunity to simulate the impact of dam removal on the morpho-sedimentary processes and rates. In this paper, we exploited this opportunity and investigated the geomorphic changes induced by dam removal in a small artificial reservoir of southern Italy (Figure 1), where the prediction ability of the Caesar-Lisflood LEM has been already tested [34]. More specifically, the calibration of the model has been recently carried out through the comparison between the simulation results and a direct estimation of sedimentation rates in the reservoir, demonstrating a good prediction ability of the model [34]. Application of the dam removal scenario in the catchment allowed us to investigate the short-term (i.e., at a decadal scale) response of the geomorphic system to the abrupt change in base level as well as the role of several local factors (i.e., infill thickness and geometry, the sediment and bedrock features) on the changes in sediment flux and channel pattern.

\section{Study Area}

The study area is located in an upland area of the Ofanto basin, a Pliocene-Quaternary tectonic depression of the southern Apennines, Italy (Figure 1). It includes the catchment of the Ficocchia Torrente stream, a dextral tributary of low hierarchical order of the Ofanto River. The Ficocchia stream is dammed in its lower reach by an earth dam (i.e., the Saetta dam), which was constructed by EIPLI (Agency for the Development of the Irrigation and Agricultural Transformation, Ministry of Agricultural, Food and Forestry Policies) between 1988 and 1989.

The Ofanto River cuts a large E-W-trending intermontane tectonic depression, Pliocene to Quaternary in age. The infill of the basin is intensively deformed by Pliocene-Pleistocene folding and faulting related to the younger stages of evolution of the southern Apennines chain [35] and covers a wide (i.e., about $350 \mathrm{kmq}$ ) and elongated area along the Ofanto River valley [36,37]. Pliocene-Pleistocene 
deposits of the Ofanto basin are composed of clay, sandstones and conglomerates, which unconformably overlay poly-deformed units of limestone, shale and sandstone that belong to the Irpinian and Lagonegro tectonic units of Cretaceous to Miocene ages [36].

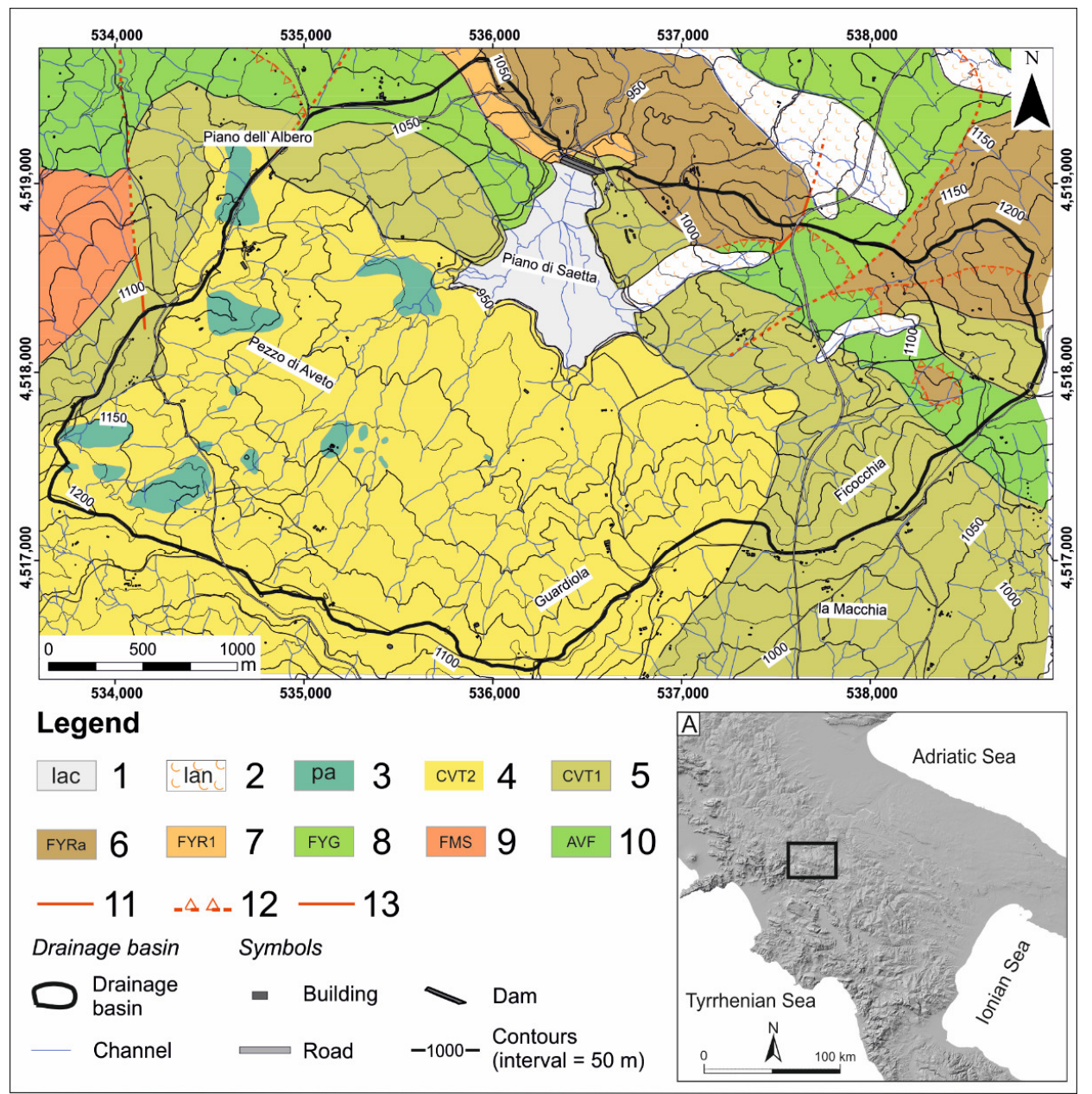

Figure 1. Geological map of the study area (modified from [36]). Legend: (1) Clay of lacustrine environment (lac, Holocene) (2) Landslide deposits (lan, Holocene) (3) Holistolits made by decametric blocks of limestone (pa, Upper Miocene); (4) Silt and marly clay (CVT2, Upper Miocene); (5) Coarse- to medium-grained sandstone with rare intercalation of lens of polygenic conglomerate (CVT1, Upper Miocene); (6) Calcareous breccia and grey shale (FYRa, Lower Cretaceous-Oligocene); (7) Alternance of chert, marly clay, calcarenites and calcareous breccia (FYR1, Lower Cretaceous-Oligocene); (8) Light-grey and greenish shale with intercalation of marls and limestone (FYG, Lower Cretaceous); (9) Alternance of calcarenite, calcilutite and varicoloured clay (FMS, Upper Cretaceous-Eocene); (10) Varicoloured clay (AVF, Lower Cretaceous); (11) High-angle fault (dashed if uncertain); (12) Thrust (dashed if uncertain); (13) Stratigraphic contact. (A) Geographical location of the study area.

The reservoir catchment is carved in a Cretaceous to Miocene bedrock made by tectonic domains belonging to Lagonegro units, Sicilide calcareous-clay succession and flysch deposits of Miocene syntectonic basins (Figure 1, see also [36]). The study area also features widespread outcroppings of upper Miocene deposits belonging to Castelvetere Formation. These deposits are composed of light brown sandstone with intercalation of conglomerate (CVT1, Figure 1) passing upward to silt and marly clay (CVT2, Figure 1) containing large blocks of olistoliths (pa, Figure 1). These deposits mainly crop out in the south-western sector of the study area and unconformably overlies the Lagonegro tectonic units, which form an elongated belt in the north-eastern sectors of the study area. The outcropping deposits of the Lagonegro units are mainly constituted by lower-middle Cretaceous marls and grey 
shales with calcarenites and calcirudites and calcareous breccia (Flysch Rosso Formation, FYRa and FYR1 in Figure 1). Lower Cretaceous varicoloured clay (AVF) with thin intercalations of calcirudites and calcarenites (FMS) crops out in the northern sector of the studied area (Figure 1).

Heterogeneous landslide deposits and fine-grained reservoir sediments are the youngest lithological units of the study area.

The geomorphological pattern of the study area is strongly influenced by the Pliocene-Quaternary tectonic evolution and relief growth of this sector of the chain, which have also controlled the lithological features and spatial distribution of deposits. The landscape is located at an altitude ranging from 942 to $1242 \mathrm{~m}$ a.s.l. and is dominated by E-W trending ridges and thrust sheets, which are mainly carved in Cretaceous-to-Miocene pelagic deposits. These structural landforms are deeply cut by the drainage network of the Ficocchia stream (Figure 2).

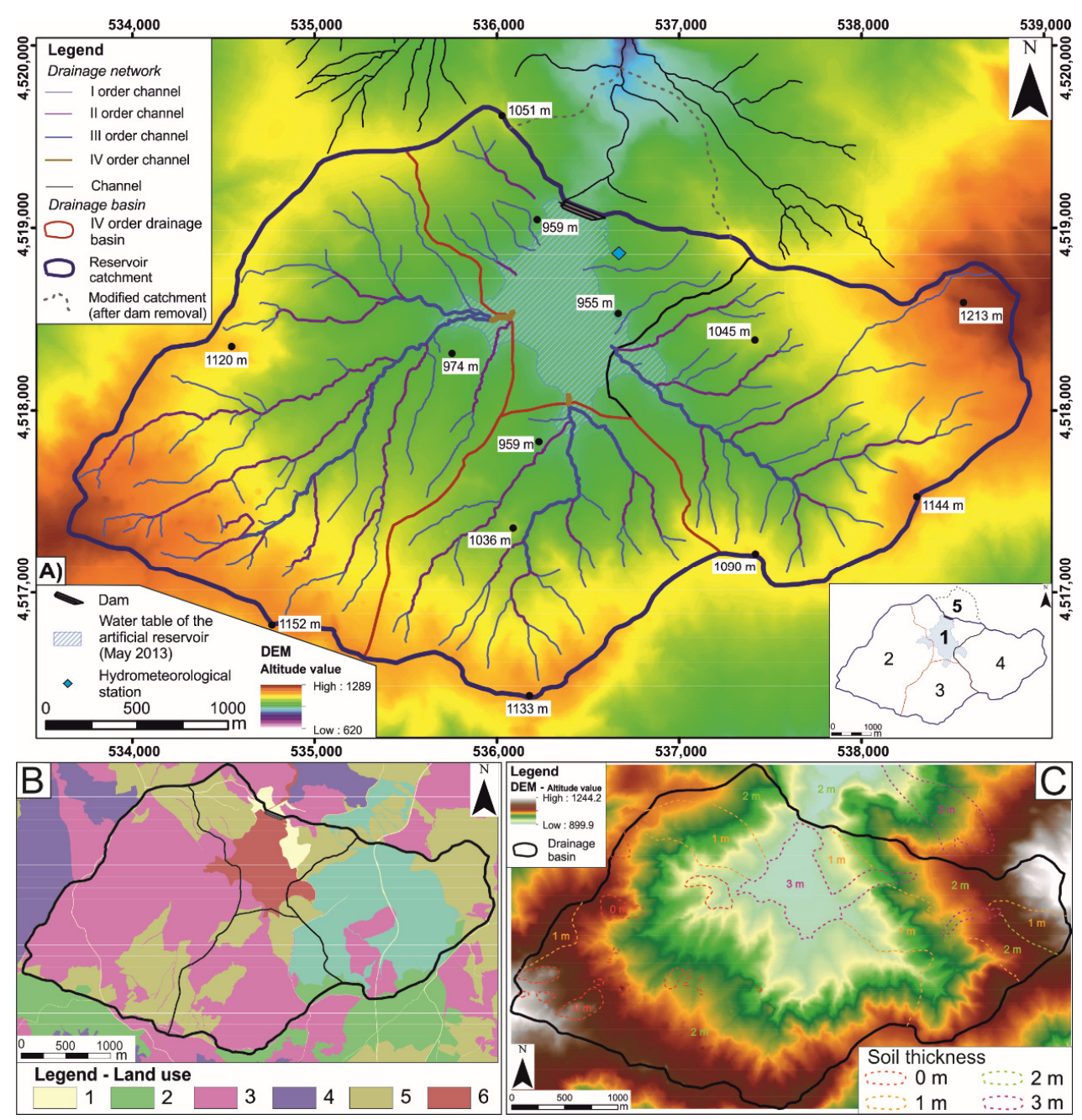

Figure 2. (A) DEM of the pre-dam removal landscape and drainage network of the study area. Hierarchization follows the Strahler's scheme. Numbering of the catchments is shown in the frame to the left. (B) Land-use map. Legend: (1) Anthropic surfaces and roads; (2) Arable lands; (3) Sclerophyllous vegetation; (4) Broad-leaved and mixed forests; (5) Natural grasslands; (6) Water courses and water bodies. (C) Isopachs of soil thickness derived by a GIS-based interpolation of the results of a field-survey analysis. Modified after [34].

The drainage basin of the artificial reservoir is formed by three small catchments of low hierarchical order showing a well-organized drainage network with a sub-dendritic pattern. The watershed of the southern sector of the reservoir catchment is featured by a sub-circular shape and runs on low-relief 
erosional land-surfaces [34,37]. In this sector, headwater channels exhibit a higher gradient than the channels located in lower reaches (Figure 2). The main geomorphological processes of the study area are channel incision and fluvial erosion, which also represent the main influence factor of the sediment yield and flux. Slope processes and landsliding phenomena related to minor shallow mass movement processes and small earth-flows are located in the eastern sector of the studied catchment, where clay-rich deposits crop out.

Regional climate data of the study area was derived from the statistical analysis of a weather station located about $20 \mathrm{~km}$ to the west of the study area (daily rainfall record of the Pescopagano weather station, period: 1951-2015, [38]). Mean annual rainfall of the study area in the last half-century is slightly higher than $1000 \mathrm{~mm}_{\text {year }}{ }^{-1}$. The climate setting is featured by dry summers and cold winters with a maximum of rainfall in autumn. In the last decades, a general trend of decrease in total annual rainfall was observed. This trend is associated with a decrease in rainy days and an increase of multi-day extreme rainfall events, mainly in autumn and spring. Shorter-term rainfall record (period: 1994-2016) of the hydro-meteorological station of the study area highlights a similar climate trend: mean annual precipitation is about $900 \mathrm{~mm}$ and rainfall peaks are mainly observed in the autumn and winter seasons, with rainfall maxima of 150-160 $\mathrm{mm}$ [34].

According to the classification of the III level of the Corine Land Cover project [39], a land-use map of the catchment was prepared from a revision of literature data and original investigation based on photointerpretation of aerial and satellite images. The landscape is dominated by semi-natural areas with natural grasslands and sclerophyllous vegetation that cover about $85 \%$ of the total area. Other sectors of the study area are classified as agricultural and urban areas.

\section{Materials and Methods}

\subsection{Caesar-Lisflood LEM: Model Description and Calibration}

Caesar-Lisflood is a second-generation LEM that can be used to model short- and long-term topographic changes and sediment flux of complex natural landscapes. In the last decade, the model was extensively used for the analysis at different temporal and spatial scales of issues of applied geomorphology and hydrology. As a matter of fact, there are at least 60 published papers dealing with model applications [40]. A rigorous and complete description is beyond the scope of this paper and is reported in [41].

The Caesar-Lisflood LEM uses a hydrological model to generate spatially distributed runoff, which is generated on a DEM to estimate flow depths and velocities [41]. Such data are used to model topographic changes and to assess topographic modification (i.e., erosion and deposition) within an active layer with a pre-defined grain-size of deposits. The modified DEM becomes the starting point for the next time step of the simulation. The user can select a catchment mode with no internal influxes other than rainfall or a reach mode, where the flow enters through the main river. Input data of the model are: DEM, grain-size features, rainfall, depth of bedrock and Manning coefficient values [24,41].

Rainfall precipitation represents the input to derivate catchment runoff, which in turn drives topographic changes (i.e., erosion and deposition) and controls fluvial and slope processes for the modeled time step [28]. Depths and velocities of the flow are estimated from flow discharges between raster cells using the Manning's equation and are then used to model both the sediment transport and erosion/deposition processes. Caesar-Lisflood estimates sediment transport in relation to nine grain-size fractions, which are selected by use. Sediment can be transported as bed load or as suspended load. Soil creep and landslide processes can be also included in the simulation [41,42] using a critical slope angle threshold. This condition allows the re-distribution of landslide and soil creep deposits from slopes to the fluvial system. Elevations and grain size features of the cells are updated according to the estimation of erosion/deposition and slope process. Model outputs are: (i) elevation changes; (ii) flow discharges; (iii) sediment fluxes at the outlet over time [24,28,41-43]. The model is able to reconstruct topographic changes at a sub-metric scale. Input data and model parameters represent the 
key to derive a robust predictive model, although a recent work by [44] demonstrated that results of the Caesar-Lisflood LEM are influenced only by a limited number of parameters. More specifically, the authors suggest that spatial distribution of Manning coefficient and the selection of the sediment transport formula are the main sensitive parameters of the model results. For this reason, we have carefully selected these parameters: for example, Einstein's sediment transport formula [45] was reconstructed using laboratory tests on (predominantly) sand-based channels and we have here chosen this equation according to the prevalent grain-size deposits of the study area. A 5-m DEM was used for the simulation. Moreover, the other input parameters were accurately derived from lithological, climate, and land-use features of the study area. To introduce a representative framework of the study area, we have preliminarily reconstructed the bedrock depth through a field-based analysis of the lithological units. To this aim, a detailed lithological map has been drawn by review of previous works and new geological surveys. Moreover, field surveys of the soil depth have been performed for the different lithological units of the study area (Figure 2, [34]). This approach allowed us to infer the soil thickness and bedrock depth for each lithological. This kind of information was summarized in a map showing the isopachs of the mean soil thickness (Figure 2c). The map has been converted in a raster grid and was introduced in the model in order to set the depth of bedrock and grain-size distribution within the active layer where erosion and deposition processes are estimated by LEM. The layer of the bedrock has been derived in a GIS environment using a map algebra tool based on a subtraction between the soil thickness map and the DEM.

Hourly rainfall dataset was derived from a weather station located near the catchment outlet. Rainfall record covers a time interval of about 22 years, and it was used also for the damremoval scenario.

Input data and model parameters are summarized in Table 1 (see also [34]). It is worthy of note that the estimation of the sedimentary budget base on the LEM simulation was already tested through a comparison between the total amount of eroded sediment volumes coming from the model results and direct measurement of the short-term (i.e., about 20 years) sediment storage within the artificial reservoir. The good accordance between the model results and direct measurements [34] suggests that the model can be used to simulate the dam removal scenario in a consistent way.

Table 1. Model parameters.

\begin{tabular}{ccc}
\hline Number & Caesar-Lisflood Parameter & Value \\
\hline 1 & Grain-size features $(\mathrm{m})$ & $0.0005,0.001,0.002,0.004,0.008,0.016,0.032,0.064,0.128$ \\
2 & Grain-size distribution (total 1$)$ & $0.20,0.18,0.12,0.06,0.03,0.03,0.1,0.25$ \\
3 & Type of rainfall record & Hourly \\
4 & Sediment transport equation & Einstein \\
5 & Max erode limit (m) & 0.01 \\
6 & Active layer thickness (m) & 0.1 \\
7 & Lateral edge smoothing passes & 40 \\
8 & Manning coefficient & $0.015-0.1$ (derived by land-use map) \\
9 & Soil creep/diffusion value & 0.0025 \\
10 & Slope failure threshold & 40 \\
11 & Vegetation critical stress & 100 \\
\hline
\end{tabular}

Manning coefficient values were assigned (Table 2) according to a revision of the values proposed in previous works (see for example [46,47]) whereas the spatial distribution of the Manning coefficient follows the boundaries of the land use map of the study area (Figure $2 b$ ). 
Table 2. Values of the Manning coefficient.

\begin{tabular}{ccc}
\hline Number & Land-Use Cover & Manning Coefficient \\
\hline 1 & Building and road & 0.015 \\
2 & Agricultural areas & 0.035 \\
3 & Sclerophyllous vegetation & 0.05 \\
4 & Broad-leaved and mixed forests & 0.1 \\
5 & Natural grasslands & 0.03 \\
6 & Streams and water bodies & 0.04 \\
\hline
\end{tabular}

\subsection{Dam-Removal Scenario}

Two different scenarios were simulated in the study area (Table 3): the first one is the pre-dam removal scenario, where the modification of the initial topography (PreDR-T0, Table 3) has been simulated over a time interval of 20 years (Pre-DR-T20, Table 3). Such a scenario represents the present-day landscape and the simulation provided a reconstruction of the sediment flux in the reservoir and the short-term topographic changes of the fluvial and slope systems. Input parameters and boundary conditions are summarized in Table 1.

Table 3. Description of the simulation scenarios: the first scenario refers to the present-day geomorphological setting whereas scenario 2 infers the geomorphic changes induced by the dam removal.

\begin{tabular}{ccccc}
\hline Scenario & Period & Initial DEM & Final DEM & Description \\
\hline 1-Pre-dam removal & $0-20 \mathrm{yr}$ & Pre-DR-T0 & Pre-Dr-T20 & $\begin{array}{c}\text { Present-day landscape, analysis of } \\
\text { erosion and sedimentation in the } \\
\text { closed drainage system } \\
\text { 2-Pemoval of dam and related }\end{array}$ \\
\hline
\end{tabular}

The post-dam removal scenario has been developed removing the dam body to the initial DEM. More specifically, the DEM was created by subtracting to the original topography the dam height (PostDR-T0, Table 3). Post-dam removal simulation was run for a period of 20 years (PostDR-T20) using the same hourly rainfall data and input parameters of the Pre-DR scenario.

Output DEMs and raster of the topographic changes were analysed in a GIS environment to assess the pattern and rates of sediment flux and channel profile adjustments. Spatial distribution of the erosion/deposition processes, multi-temporal analysis of river longitudinal profiles, and valley topographic changes represent the key data to infer the geomorphic response of the study area to the simulated fall of the base-level.

\section{Results}

\subsection{Scenario 1, Pre-Dam Removal}

Outputs of the Caesar-Lisflood LEM are analysed in a GIS environment in order to investigate the geomorphic changes of the fluvial system and the spatial and temporal distribution of sediment erosion and deposition and their relationships with lithology, land use, and geomorphological processes. Figure 3 shows the hillshades representing the initial DEMs used for the modeling of the two simulation scenarios. Dam removal promoted an increase of the catchment area of about $0.6 \mathrm{kmq}$. The post-dam removal catchment includes the steeper reach of the Ficocchia stream, which flows in a deep V-shape valley.

As already described in the previous section, a recent work provided a comparison between LEM-based estimation of sediment flux of the Ficocchia catchment and direct measurements of reservoir sedimentation volumes [34]. This estimation covers a period (i.e., 18 years) similar to the simulation period of this work and highlights good accordance between model results and field-based data. 
More specifically, LEM-based erosion volumes tend to underestimate the reservoir sedimentation of about $20 \%$.
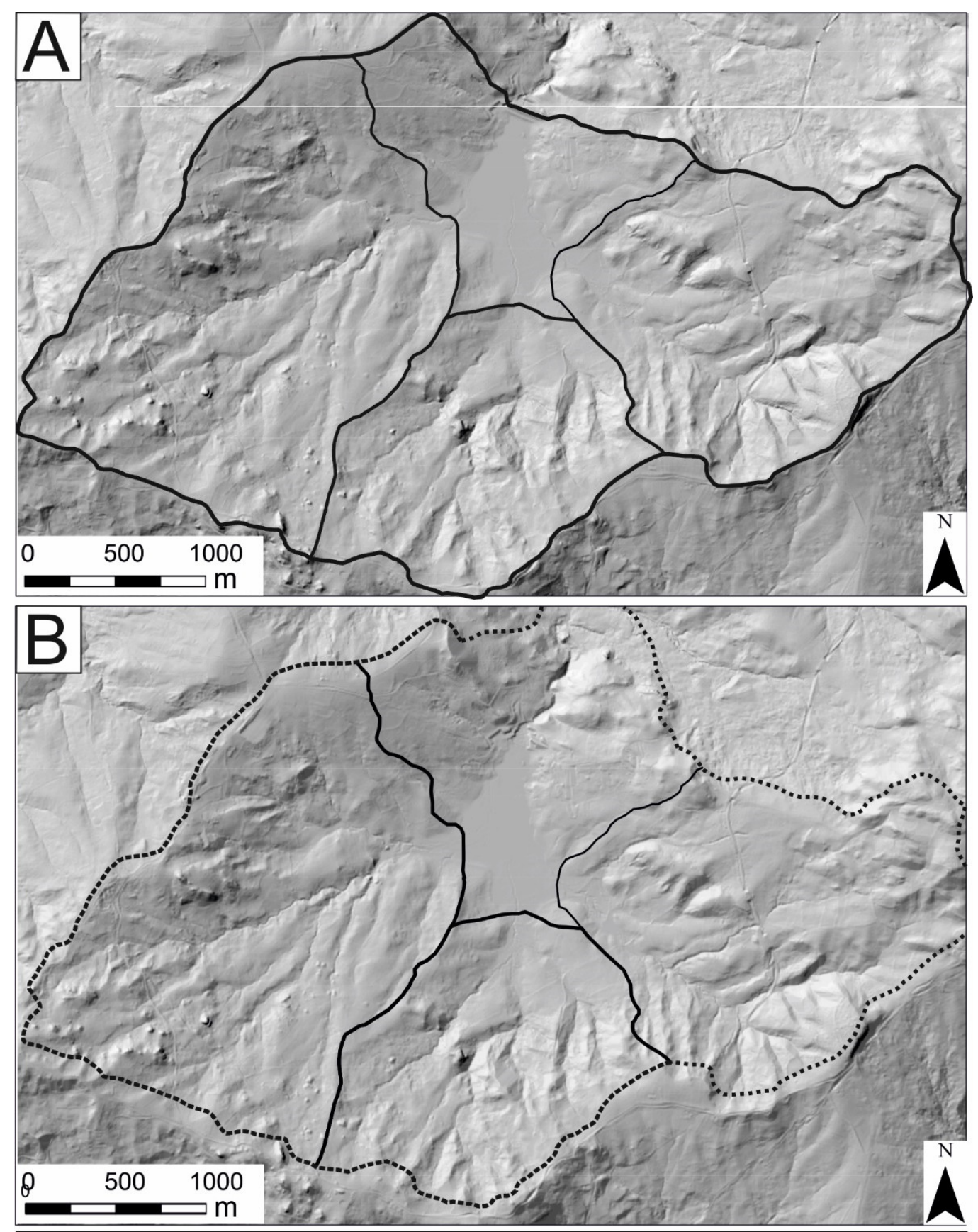

\section{Legend \\ $\square$ III order drainage basin $\bigcirc$ Reservoir catchment

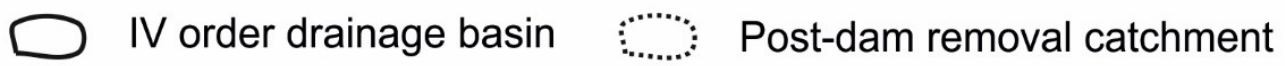

Figure 3. Hillshades representing the initial DEMs used for the modeling of the different simulation scenarios: (A) pre-dam removal, initial topography (PreDR-T0); (B) post-dam removal, simulation period: 1 year (PostDR-T0). 
Simulation results of the pre-dam removal scenario are summarized in a DEM of difference (Figure 4), which shows the topographic changes at a sub-metric scale and sediment flux in the study area after 20 years. Visual inspection of the map allowed us to infer the short-term morpho-sedimentary evolution of mountain catchments and the influence of fluvial and hillslope processes on the geomorphological evolution and sediment delivery. The map highlights that erosion processes occurred along the main channels of the fluvial net whereas deposition is located in the artificial reservoir as a result of the flattening of longitudinal profiles in the lower reaches of the channels (Figure 4).

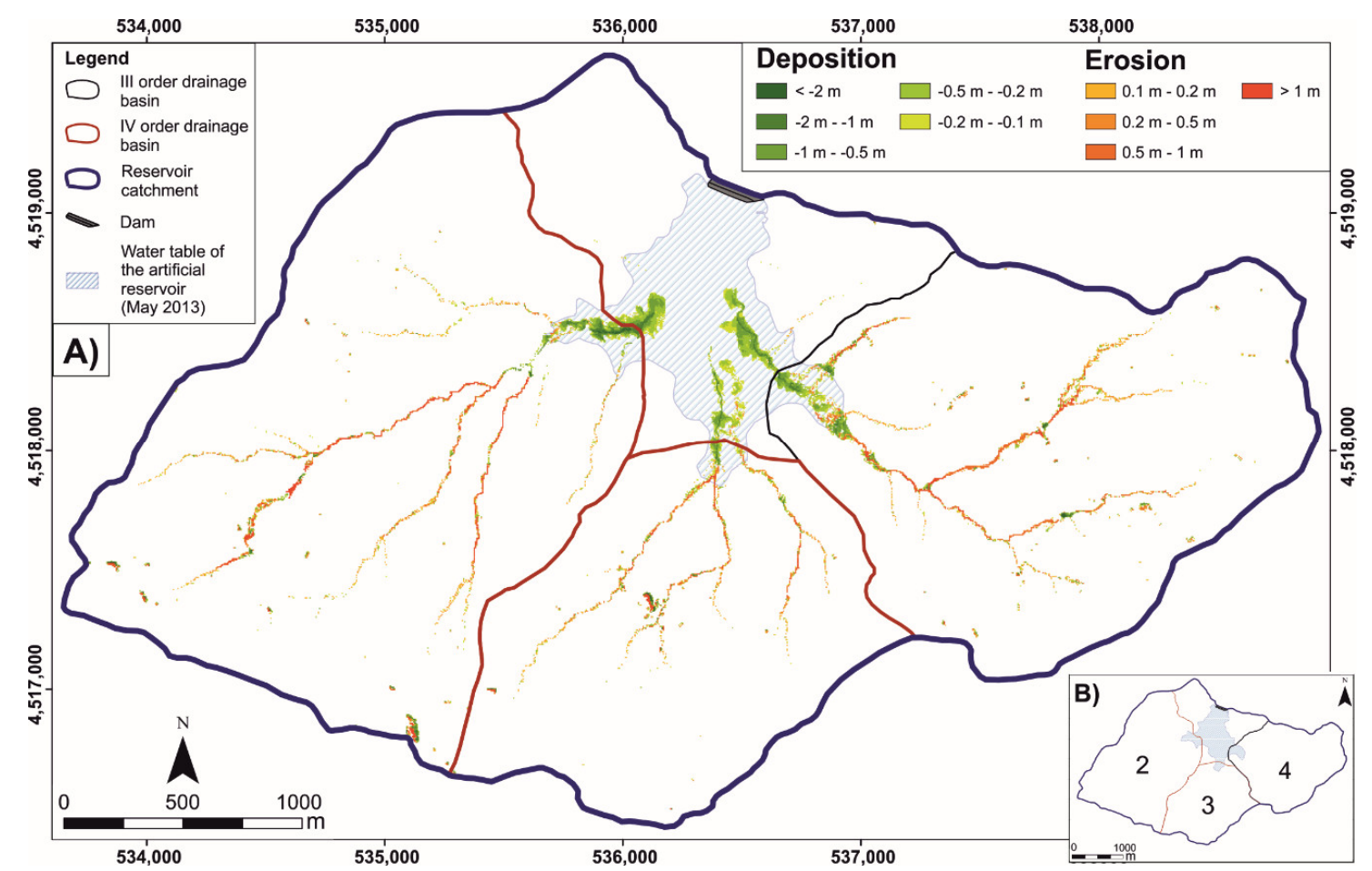

Figure 4. (A) Elevation difference map for the pre-dam removal scenario (simulation period: 20 years); (B) Numbering of the three sub-basins of the study area.

Model results seem to suggest a minor impact of slope processes on the sediment yield of the studied catchment, although landslide processes and high levels of the reservoir water table have been invoked as possible factors of slight differences between LEM-based erosion volumes and direct estimation of reservoir sedimentation [34]. In any case, modelling results fit well with the spatial distribution of landforms and deposits deriving by field-based geomorphological analysis. In fact, several geomorphological evidences such as V-shape valleys of the main channels and the absence of slope and alluvial deposits along the thalwegs is in accordance with the LEM results and suggest that channel incision upstream of the artificial reservoir is the main geomorphological processes controlling the morpho-sedimentary evolution of the Ficocchia catchment. As a matter of fact, sediment delivery ratio of the artificial reservoir is slightly higher than 0.9 , testifying a high level of sediment connectivity of the study area.

Histogram of Figure 5 shows the results of the elevation changes caused by erosion and deposition after a time interval of 20 years. The total amount of erosion deriving by Caesar-Lisflood LEM simulation for the entire period is $84,070 \mathrm{~m}^{3}$, which corresponds to a mean annual erosion volume of $4203 \mathrm{~m}^{3}$ /year (Figure 5). Stable areas represent $97.7 \%$ of the total area whereas the most representative erosion class has a value ranging from 0.1 to $0.5 \mathrm{~m}$ (Figure 5). Analysis of the contribution of each sub-basin to the sediment yield highlights that about $83 \%$ of the total amount of erosion volumes comes from catchment n.2 and n.4 (Figure 5). 


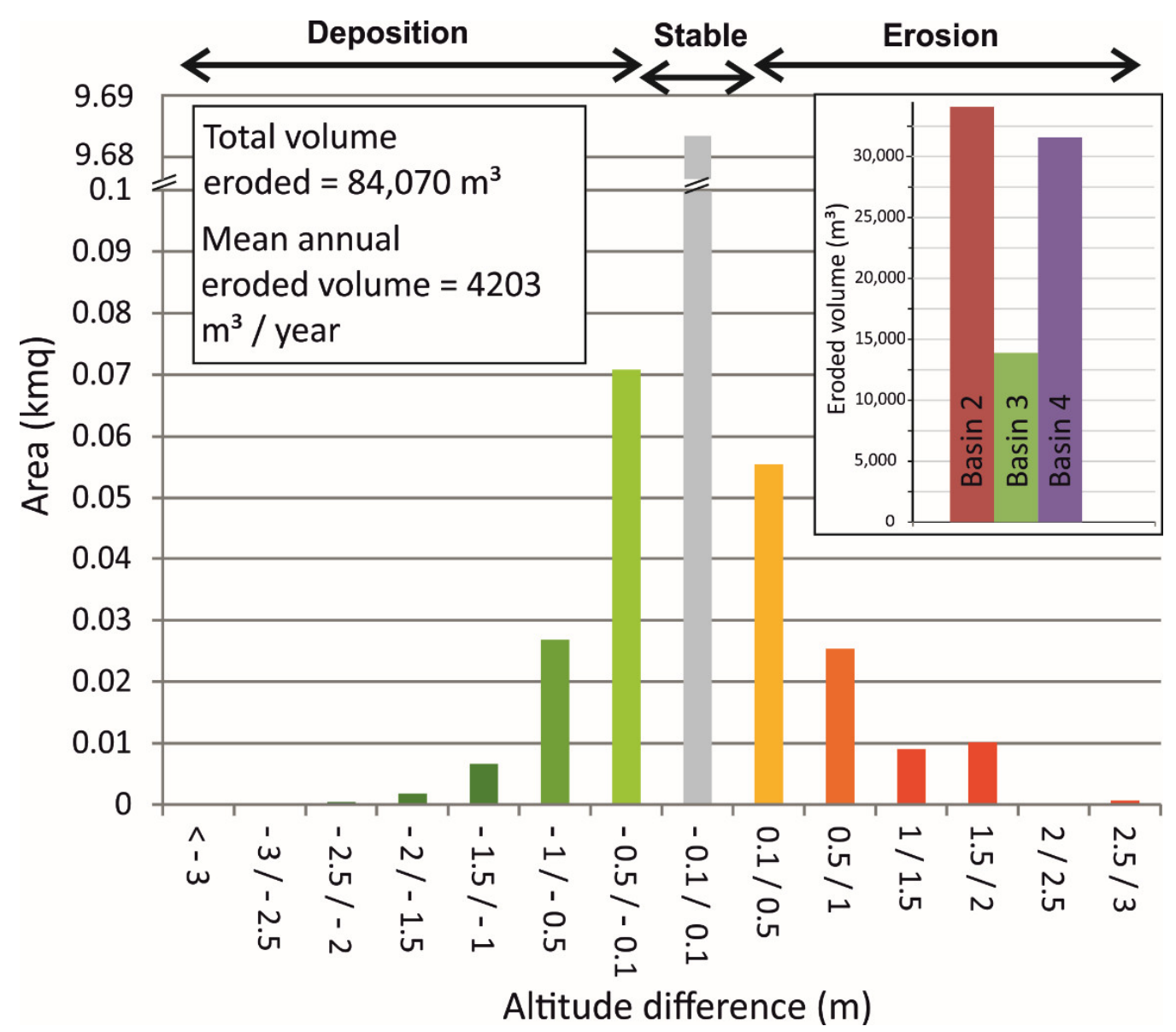

Figure 5. Erosion/deposition classes in the catchment deriving from the analysis of the altitude difference map of Figure 4. In the frame: distribution of the eroded volumes from the three sub-basins of the study area (numbering is shown in Figure 4).

\subsection{Scenario 2-Dam Removal}

Post-dam removal scenario (Post-DR, Table 3) was carried out over a 20-year period to perform a direct comparison with the sediment budget related to Scenario 1. Decadal-scale modelling of the geomorphic response to dam-removal predicts a strong modification of the fluvial system, with a general increase of topographic changes than the pre-dam removal scenario (Cfr. Figures 4 and 6). Altitude difference map (Figure 6) clearly highlights a significant increase of erosion processes in both the headwaters and mid sectors of the drainage net, which are mainly related to the higher incision ability of the main channels. In fact, a comparison between the results of the two simulations shows that lateral migration of channels appears to be limited (cf. Figures 4 and 6). LEM predicts the development of a wide floodplain in the flat area of the reservoir with a well-defined incision of the infill by the three main channels of the study area. In addition, analysis of the spatial pattern of erosion and deposition shows the occurrence of small sedimentation areas upstream to the reservoir infill (Figure 6), which contributed to a slight decrease of the sediment connectivity of the entire catchment. 


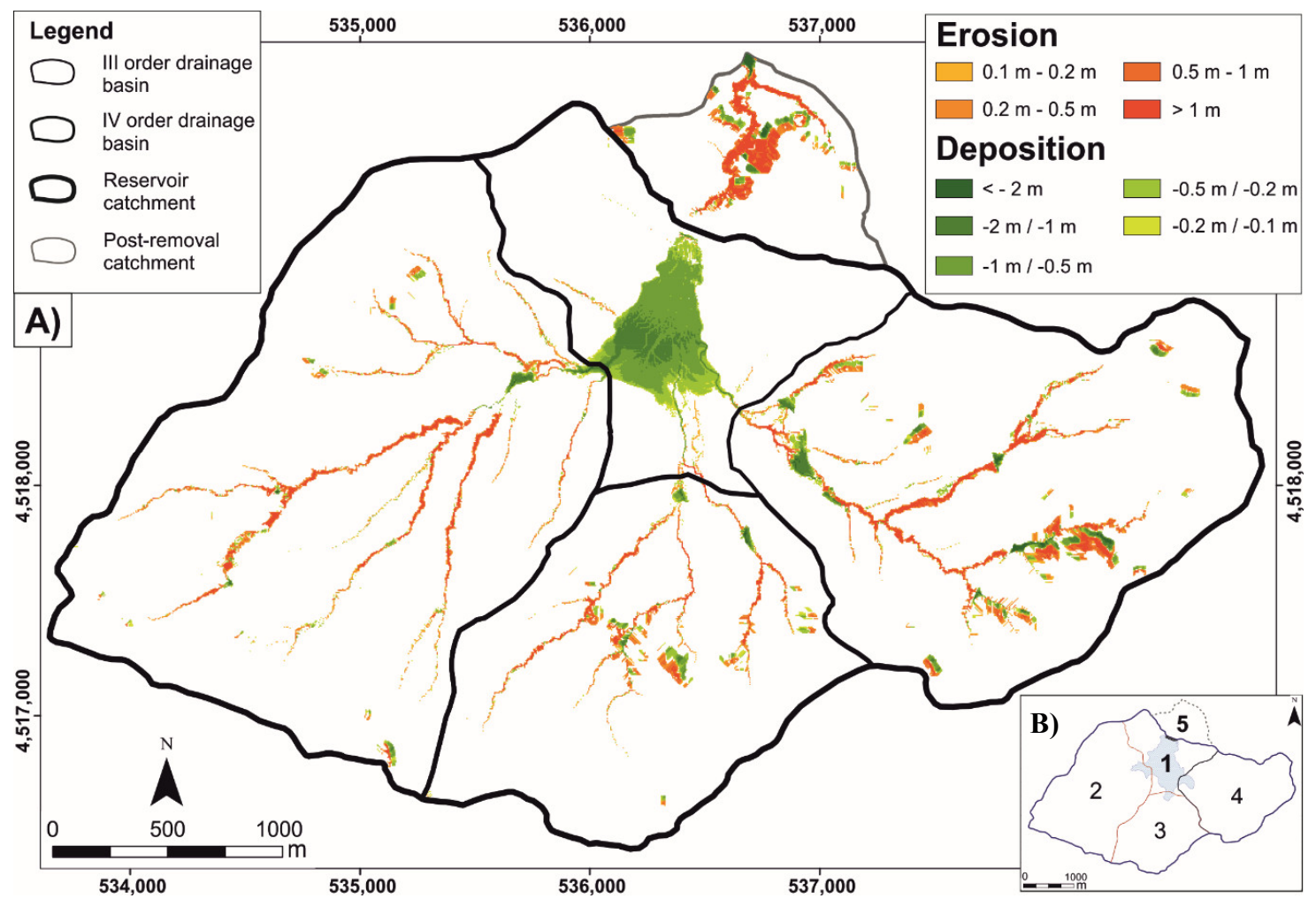

Figure 6. (A) Landscape evolution models (LEM)-based elevation difference map for the post-dam removal scenario (simulation period: 20 years). (B) Numbering of the post-dam removal catchments.

The frequency distribution of the altitude difference map (Figure 7) illustrates a higher erosional ability of the geomorphic system after the lowering of the base level.

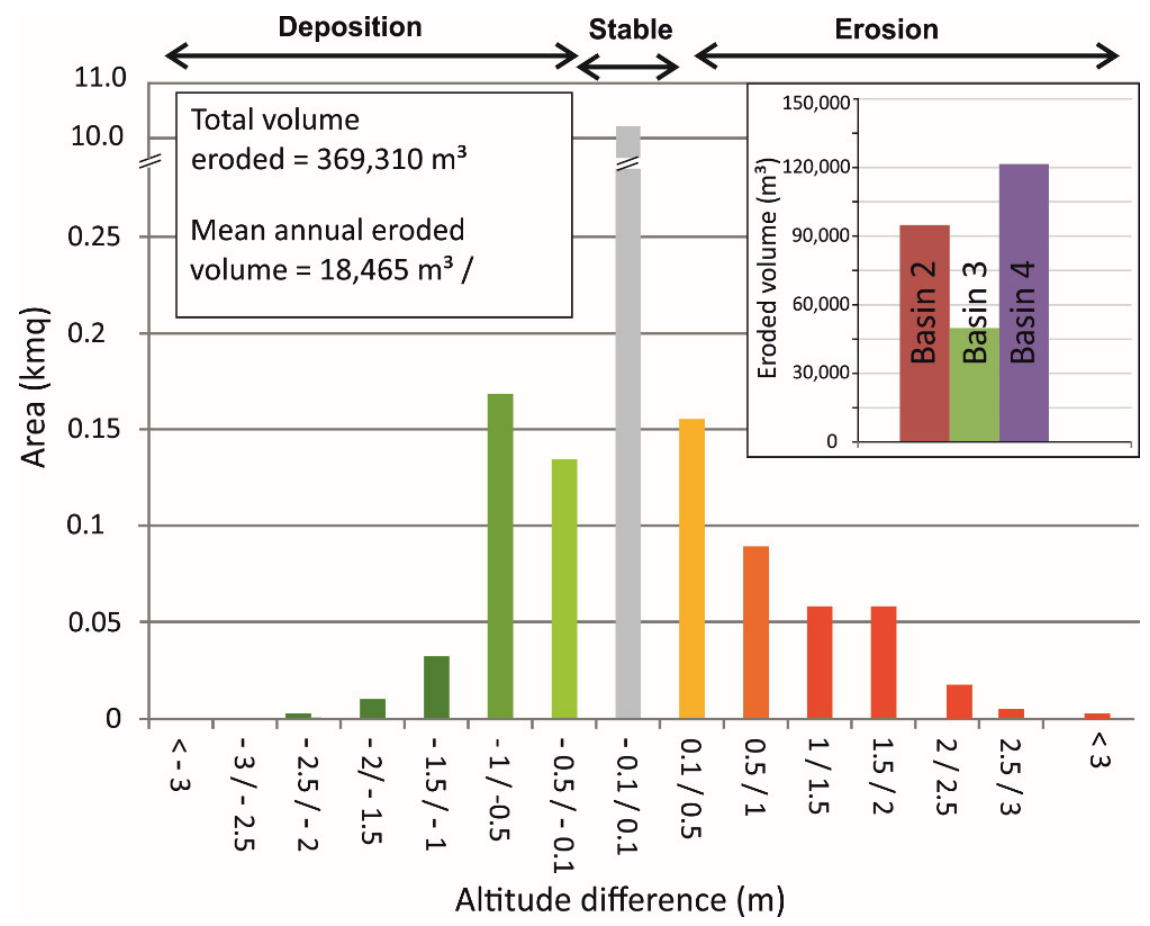

Figure 7. Statistical distribution of the altitude difference map of Figure 6 (Post-dam removal scenario). In the frame: distribution of the eroded volumes from the three sub-basins of the study area (numbering is shown in Figure 6). 
In fact, the model predicts an increase of the total eroded volumes by a factor of 4.4 for the post-dam removal scenario whereas the mean annual erosion volumes increase from $4203 \mathrm{~m}^{3} /$ year to 18465 (Figure 7). Caesar-Lisflood simulation infers topographic modifications for a percentage of the total area of about $7.1 \%$ (corresponding to an area of $0.74 \mathrm{kmq}$ ). In this scenario, erosion classes with a value ranging from 0.1 to $0.5 \mathrm{~m}$ represent the maximum of the altitude difference map but the comparison with Scenario 1 shows a relative increase of the erosion classes with a higher value. Analysis of the spatial pattern of erosion for the different sectors of the study area shows that sub-basin 4 and 3 contribute to $45.7 \%$ and $18.7 \%$ of the total amount of eroded volumes yielded in the upland sectors.

Then, approximately $81.3 \%$ of the total amount of sediment eroded comes from sub-basin n. 3 and n.4 (i.e., the easternmost and the central one), highlighting a higher erosion ability of these catchments for the dam removal scenario.

\subsection{River Profile Analysis and Channel/Valley Modifications}

Multitemporal analysis of longitudinal river profiles has been performed using the elevation data derived from the output DEMs for each scenario. The perturbation induced by the dam removal promoted a significant modification of the river profiles (Figure 8), with a complex spatial and temporal pattern of geomorphic adjustments. Moreover, our simulation also highlights the occurrence of 2-D channel modifications, which are mainly related to a lateral shift of the main channels in the higher altitude sectors surrounding the reservoir infill (Figure 8).

After the dam removal, the longitudinal profile evolution is mainly featured by a pronounced channel incision, which mainly occurred upward the flat area of the reservoir (Figure 8). In fact, the fast response of main channels to the base-level lowering is a lengthening of the longitudinal profiles, which promoted incision upstream of the former reservoir area (Figure 8, see the yellow curves and the black ones). Channel 2 adjusts its longitudinal profiles forming a major convex knickzone downstream of the removed dam, which retreats of about 180-200 m during the 20-year simulation period. A minor knickpoint can be observed in the three channels at an altitude of about 955-960 m, showing a lower rate of retreat (i.e., about $1 \mathrm{~m} / \mathrm{yr}$ ).

Cross profiles of Figure 9 furnished additional information about the landscape modification resulting from our simulation. Spatial and temporal evolution of valley/channel modification is complex, with alternating stages of incision and aggradation. Profiles located in the higher altitude sectors of the catchment are featured by meter-scale incision (see for example profile $a-a^{\prime}, d-d^{\prime}$ and e-e'); in this sector, the highest amount of deepening (i.e., about $3 \mathrm{~m}$ ) can be observed at profile a-a'. Topographic profiles crossing the reservoir deposits shows a more complex response to dam removal due to a general tendency of channels to cut the infill in the southernmost sectors (Figure 9, see profile $\mathrm{b}-\mathrm{b}^{\prime}$ and $\mathrm{f}-\mathrm{f}^{\prime}$ ) and the occurrence of aggradation upward the removed dam (see for example the profile $\mathrm{g}-\mathrm{g}^{\prime}$, Figure 9). Pronounced incision phenomena occurred downstream of the dam, with a progressive deepening of the main channels of about $3 \mathrm{~m}$ over the 20-year simulation period (Figure 9, profile i-i' and $\left.1-1^{\prime}\right)$. 

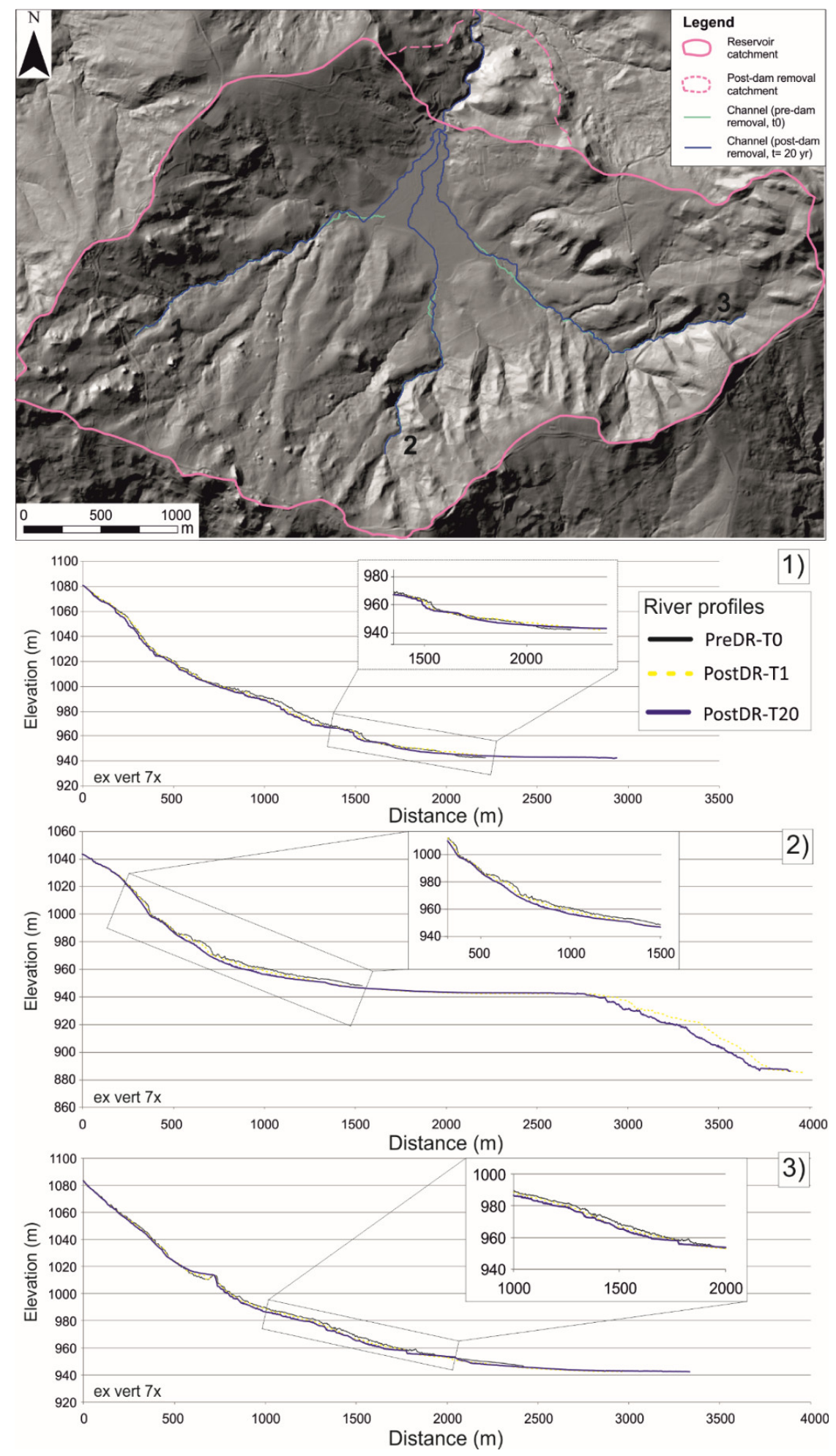

Figure 8. Map showing the planimetric changes of the main channels from the present-day landscape (initial DEM, Pre-DR-T0 in Table 3) to the final stage of the post-dam removal scenario. To the bottom: comparison of longitudinal river profiles of the three main channels (channel 1, 2 and 3 in the map) deriving from the simulation scenarios. River profile analysis highlights the amount of incision related to the base-level fall as well as the development of pronounced knickpoints in the upper and lower reaches of the main channels. Higher rates of knickpoint retreat are associated with the lower reach of the channel 2. 

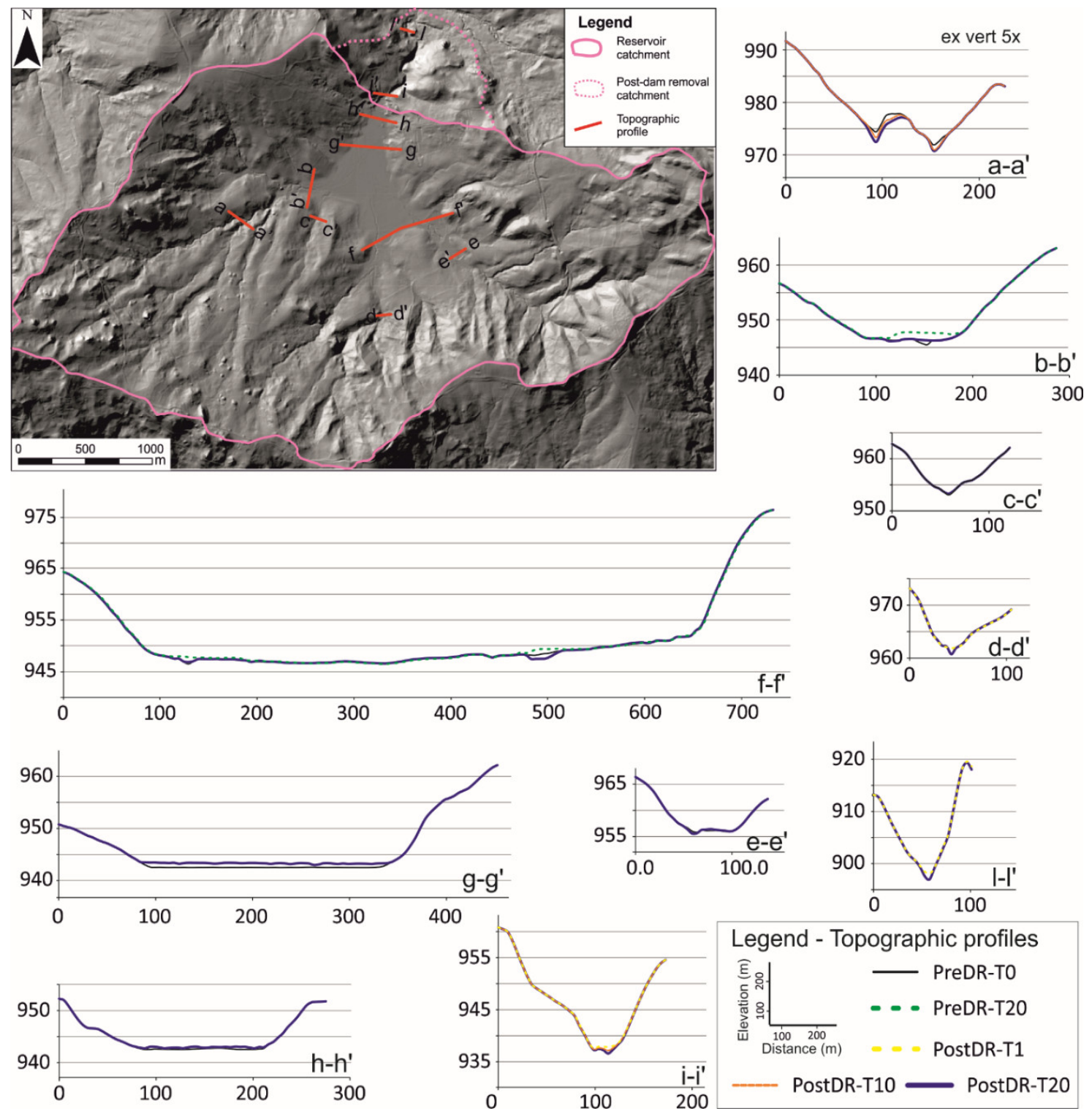

Figure 9. Topographic profiles for the different simulation scenarios (location of the profile is reported in the map) showing the landscape modification resulting from the simulation. Higher rates of fluvial incision occurred in the upper and lower reaches of the catchment (about 3 m over the 20-year simulation period, see for example profile a-a' and i-i'). A deep incision of the reservoir top can be also observed.

\section{Discussion}

LEM-based simulation of the geomorphic response of an upland catchment of southern Italian Apennine to dam removal suggests a complex spatial and temporal modification of channels and sediment flux. Model calibration and selection of the appropriate input parameters and boundary conditions are a critical issue for the LEM application in complex landscapes. (Skinner et al., 2018) [44] provided a detailed sensitivity analysis of the Caesar-Lisflood LEM, demonstrating that only some parameters such as sediment transport formula, Manning coefficient, and sediment grain sizes have a significant influence on model results.

Our approach based on a calibration of the model using direct measurements of sedimentation volumes in the artificial reservoir overcomes the issue of the complex selection of an excessive number of input and model parameters of the Caesar-Lisflood LEM, which are frequently ascribed as the main factor of its rare application $[33,34,44]$. 
In the study area, these parameters have been here derived by detailed field measurements and calibrated by the evaluation of an independent dataset. The preliminary validation of the short-term prediction ability of the Caesar-Lisflood LEM deriving from a direct comparison between model results and direct measurements of reservoir sedimentation volumes is a strong point of the proposed approach, which suggests the robustness of the model settings and parameterization. In fact, the limited difference between source-sink data confirms the robustness of the model and allowed us to consider our simulation as a robust estimation of topographic changes, geomorphological processes, and sediment flux at a short-term scale (i.e., 20 years) induced by base-level lowering. Such an approach can be effectively integrated with short-term analysis of geomorphic processes based on multitemporal comparison of high-resolution DEMs [48,49] and/or quantitative geomorphological analyses [8,50-52].

Our investigation demonstrated that Caesar-Lisflood LEM has a high potential to explore scenarios of morpho-sedimentary changes in response to different perturbing factors such as base-level fall or climate/land-use changes. The main advantage of the use of the LEM is its ability to reconstruct 2-D topographic modification and sediment flux, which can be investigated through advanced GIS-tools of map algebra and spatial statistics.

The geomorphic response to dam-removal scenario of the Ficocchia catchment mainly consists of a higher erosion ability of the channels in the upper reaches of the fluvial systems and a deep incision in the lowermost sectors of the post-dam removal catchment. As a matter of fact, quantitative analysis of the sediment dynamics resulting from the dam-removal scenario highlights a significant increase of the total eroded volumes in the post dam scenario of a factor higher than four. This significant increase of sediment yield is a common response of the fluvial system to base-level lowering, although our predicted erosion rates of the study area after the dam removal are significantly higher than the estimation coming from previous works (see for example [32]). For example, a recent analysis of the impact of multiple dam removal using Caesar-Lisflood LEM [32] reported a lower amount of sediment delivery induced by such a dam removal scenario.

This kind of response of the fluvial system to base-level lowering is in accordance with reconstruction made by other studies since it is mainly represented by upstream widespread incision associated to knickpoint retreat $[17,19,21,32]$.

Predicted rates of knickpoint retreat reached values lower than those predicted by other researchers [32,53]. For example, a recent LEM-based analysis of multiple removals of narrow dams in Austria predicted annual knickpoint retreat rates ranging from 150 to $300 \mathrm{~m}$ [32], which is an order of magnitude higher than our results. As a matter of fact, our analysis highlights a peak of knickpoint retreat for the main channels of about $10 \mathrm{~m} / \mathrm{yr}$, see Figure 9).

The presence of a wide flat landscape coinciding with the former reservoir could represent the external factor that drives the complex and peculiar response of the study area. This sector can promote the dysconnectivity between the two steeper segments of the longitudinal profiles located upward and downward the removed dam, which could inhibit a faster retreat of the major knickpoint related to dam removal and promoted the formation of a wide floodplain in the mid sectors of the catchment. This observation confirms the relevant role of local parameters and physiographic setting (i.e., geometry and sedimentary features of the reservoir infill, bedrock and sediment erodibility, channel profile slope, etc.) in controlling the spatial distribution of erosion/deposition processes and the response of the fluvial system to severe perturbations induced by a fast base-level lowering, thus emphasizing the crucial role of landscape evolution models in the reconstruction of complex spatial and temporal changes of erosion and deposition induced by human disturbances.

\section{Concluding Remarks}

Simulation scenarios of sediment flux variation and topographic changes due to dam removal have been investigated in a reservoir catchment of southern Italy through the application of a landscape evolution model (i.e.: the Caesar-Lisflood LEM). LEM simulation highlights that the abrupt change in base-level due to dam removal induces a significant increase in erosion ability of main channels 
and a strong incision of the reservoir infill. Analysis of the sediment dynamics resulting from the dam-removal highlights a significant increase of the total eroded volumes in the post dam scenario of a factor higher than four. Model results also predict a strong modification of the longitudinal profile of main channels induced by dam removal, which promoted deep fluvial incision in their upper and lower reaches.

Results are in agreement with previous analysis of the short-term response of the fluvial system, thus demonstrating the reliability of LEM-based analysis for solving open problems of short-term topographic changes and sedimentary budget induced by natural or human perturbations. The general good accordance between the model results and independent analysis based on field data ([34], see also paragraph 4.1) demonstrated both the general usefulness of the approach for the investigation of human-induced geomorphic disturbance of a landscape and the usefulness of the proposed approach than the application of 1-D simplified models. The main advantage of the use of the Caesar-Lisflood LEM in reconstructing the 2-D spatial and temporal pattern of topographic changes and related geomorphological processes is that the simulation scenarios can be easily compared with field data and historical maps, which can be also useful to explore the source of uncertainties, simplifications, and assumptions of the model.

Author Contributions: Conceptualization, D.G. and M.S.; methodology, D.G. and M.S.; software, D.G.; validation, D.G. and M.S.; formal analysis, D.G.; investigation, D.G. and M.S.; resources, D.G. and M.S.; data curation, D.G.; writing — original draft preparation, D.G.: writing—review and editing, D.G. and M.S.; visualization, D.G. and M.S.; supervision, D.G. and M.S.; project administration, D.G. and M.S.; funding acquisition, D.G. and M.S. All authors have read and agreed to the published version of the manuscript.

Funding: This research received no external funding.

Acknowledgments: We would like to thank the three anonymous referees for their helpful suggestions and constructive reviews. The first author would also like to thank Maurizio Lazzari (ISPC-CNR) for support in fieldwork and interesting discussions.

Conflicts of Interest: The authors declare no conflict of interest.

\section{References}

1. Dente, E.; Lensky, N.G.; Morin, E.; Grodek, T.; Sheffer, N.A.; Enzel, Y. Geomorphic Response of a Low-Gradient Channel to Modern, Progressive Base-Level Lowering: Nahal HaArava, the Dead Sea. J. Geophys. Res. Earth Surf. 2017, 122, 2468-2487. [CrossRef]

2. Neave, M.; Rayburg, S.; Swan, A. River channel change following dam removal in an ephemeral stream. Aust. Geogr. 2009, 40, 235-246. [CrossRef]

3. Joeckel, R.M.; Diffendal, R.F., Jr. Geomorphic and environmental change around a large, aging reservoir: Lake C. W. McConaughy, Western Nebraska, USA. Environ. Eng. Geosci. 2004, 10, 69-90. [CrossRef]

4. Struth, L.; Garcia-Castellanos, D.; Viaplana-Muzas, M.; Vergés, J. Drainage network dynamics and knickpoint evolution in the Ebro and Duero basins: From endorheism to exorheism. Geomorphol 2019, 327, 554-571. [CrossRef]

5. Rodríguez-Rodríguez, L.; Antón, L.; Pallàs, R.; García-Castellanos, D.; Jiménez-Munt, I.; Pastor-Martín, C. A GIS method to identify flat surfaces and restore relict fluvial long-profiles from terrace remnants gives new clues on how large basins respond to endorheic-exorheic transitions (Duero basin, Iberian Peninsula). Earth Surf. Process. Landf. 2020, 45, 1013-1027. [CrossRef]

6. Bilmes, A.; Veiga, G.D.; Ariztegui, D.; Castelltort, S.; D’Elia, L.; Franzese, J.R. Quaternary base-level drops and trigger mechanisms in a closed basin: Geomorphic and sedimentological studies of the Gastre Basin, Argentina. Geomorphology 2017, 283, 102-113. [CrossRef]

7. Cunha, P.P.; Martins, A.A.; Gomes, A.; Stokes, M.; Cabral, J.; Lopes, F.C.; Antón, L. Mechanisms and age estimates of continental-scale endorheic to exorheic drainage transition: Douro River, Western Iberia. Glob. Planet. Chang. 2019, 181, 102985. [CrossRef]

8. Buccolini, M.; Materazzi, M.; Aringoli, D.; Gentili, B.; Pambianchi, G.; Scarciglia, F. Late Quaternary catchment evolution and erosion rates in the Tyrrhenian side of central Italy. Geomorphology 2014, 204, 21-30. [CrossRef] 
9. Giano, S.I.; Gioia, D.; Schiattarella, M. Morphotectonic evolution of connected intermontane basins from the southern Apennines, Italy: The legacy of the pre-existing structurally controlled landscape. Rend. Lincei 2014, 25, 241-252. [CrossRef]

10. Gioia, D.; Gallicchio, S.; Moretti, M.; Schiattarella, M. Landscape response to tectonic and climatic forcing in the foredeep of the southern Apennines, Italy: Insights from Quaternary stratigraphy, quantitative geomorphic analysis, and denudation rate proxies. Earth Surf. Process. Landf. 2014, 39, 814-835. [CrossRef]

11. Amato, A.; Aucelli, P.P.C.; Cinque, A. The long-term denudation rate in the Southern Apennines Chain (Italy): A GIS-aided estimation of the rock volumes eroded since middle Pleistocene time. Quat. Int. 2003, 101, 3-11. [CrossRef]

12. Capolongo, D.; Refice, A.; Bocchiola, D.; D'Addabbo, A.; Vouvalidis, K.; Soncini, A.; Stamatopoulos, L. Coupling multitemporal remote sensing with geomorphology and hydrological modeling for post flood recovery in the Strymonas dammed river basin (Greece). Sci. Total Environ. 2019, 651, 1958-1968. [CrossRef] [PubMed]

13. Burroughs, B.A.; Hayes, D.B.; Klomp, K.D.; Hansen, J.F.; Mistak, J. Effects of Stronach Dam removal on fluvial geomorphology in the Pine River, Michigan, United States. Geomorphology 2009, 110, 96-107. [CrossRef]

14. Major, J.J.; East, A.E.; O'Connor, J.E.; Grant, G.E.; Wilcox, A.C.; Magirl, C.S.; Tullos, D.D. Geomorphic responses to dam removal in the United States-A two-decade perspective. Gravel Bed Rivers Process Disasters 2017, 355-383. [CrossRef]

15. Wang, H.-W.; Kuo, W.C. Geomorphic Responses to a Large Check-Dam Removal on a Mountain River in Taiwan. River Res. Appl. 2015, 32, 1094-1105. [CrossRef]

16. Randle, T.J.; Bountry, J.A.; Ritchie, A.; Wille, K. Large-scale dam removal on the Elwha River, Washington, USA: Erosion of reservoir sediment. Geomorphology 2015, 246, 709-728. [CrossRef]

17. Gartner, J.D.; Magilligan, F.J.; Renshaw, C.E. Predicting the type, location and magnitude of geomorphic responses to dam removal: Role of hydrologic and geomorphic constraints. Geomorphology 2015, 251, 20-30. [CrossRef]

18. Pearson, A.J.; Snyder, N.P.; Collins, M.J. Rates and processes of channel response to dam removal with a sand-filled impoundment. Water Resour. Res. 2011, 47, W08504. [CrossRef]

19. Sawaske, S.R.; Freyberg, D.L. A comparison of past small dam removals in highly sediment-impacted systems in the U.S. Geomorphology 2012, 151, 50-58. [CrossRef]

20. Walter, C.; Tullos, D.D. Downstream channel changes after a small dam removal: Using aerial photos and measurement error for context; Calapooia River, Oregon. River Res. Appl. 2010, 26, 1220-1245. [CrossRef]

21. Wells, R.R.; Langendoen, E.J.; Simon, A. Modeling Pre- and Post-Dam Removal Sediment Dynamics: The Kalamazoo River, Michigan1. Jawra J. Am. Water Resour. Assoc. 2007, 43, 773-785. [CrossRef]

22. Cui, Y.; Parker, G.; Braudrick, C.; Dietrich, W.E.; Cluer, B. Dam Removal Express Assessment Models (DREAM). J. Hydraul. Res. 2006, 44, 308-323. [CrossRef]

23. Benaïchouche, A.; Stab, O.; Tessier, B.; Cojan, I. Evaluation of a landscape evolution model to simulate stream piracies: Insights from multivariable numerical tests using the example of the Meuse basin, France. Geomorphology 2016, 253, 168-180. [CrossRef]

24. Coulthard, T.J.; Hancock, G.R.; Lowry, J.B.C. Modelling soil erosion with a downscaled landscape evolution model. Earth Surf. Process. Landf. 2012, 37, 1046-1055. [CrossRef]

25. Temme, A.J.A.M.; Peeters, I.; Buis, E.; Veldkamp, A.; Govers, G. Comparing landscape evolution models with quantitative field data at the millennial time scale in the Belgian loess belt. Earth Surf. Process. Landf. 2011, 36, 1300-1312. [CrossRef]

26. Van Gorp, W.; Temme, A.J.; Baartman, J.E.; Schoorl, J.M. Landscape Evolution Modelling of naturally dammed rivers. Earth Surf. Process. Landf. 2014, 39, 1587-1600. [CrossRef]

27. Refice, A.; Giachetta, E.; Capolongo, D. SIGNUM: A Matlab, TIN-based landscape evolution model. Comput. Geosci. 2012, 45, 293-303. [CrossRef]

28. Coulthard, T.J.; van de Wiel, M.J. Modelling long term basin scale sediment connectivity, driven by spatial land use changes. Geomorphology 2017, 277, 265-281. [CrossRef]

29. Hancock, G.R.; Coulthard, T.J.; Martinez, C.; Kalma, J.D. An evaluation of landscape evolution models to simulate decadal and centennial scale soil erosion in grassland catchments. J. Hydrol. 2011, 398, 171-183. [CrossRef] 
30. Tucker, G.E.; Hancock, G.R. Modelling landscape evolution. Earth Surf. Process. Landf. 2010, 35, 28-50. [CrossRef]

31. Lowry, J.B.C.; Narayan, M.; Hancock, G.R.; Evans, K.G. Understanding post-mining landforms: Utilising pre-mine geomorphology to improve rehabilitation outcomes. Geomorphology 2019, 328, 93-107. [CrossRef]

32. Poeppl, R.E.; Coulthard, T.; Keesstra, S.D.; Keiler, M. Modeling the impact of dam removal on channel evolution and sediment delivery in a multiple dam setting. Int. J. Sediment Res. 2019, 34, 537-549. [CrossRef]

33. Temme AJ, A.M.; Claessens, L.; Veldkamp, A.; Schoorl, J.M. Evaluating choices in multi-process landscape evolution models. Geomorphology 2011, 125, 271-281. [CrossRef]

34. Gioia, D.; Lazzari, M. Testing the Prediction Ability of LEM-Derived Sedimentary Budget in an Upland Catchment of the Southern Apennines, Italy: A Source to Sink Approach. Water 2019, 11, 911. [CrossRef]

35. Schiattarella, M.; Giano, S.I.; Gioia, D. Long-term geomorphological evolution of the axial zone of the Campania-Lucania Apennine, southern Italy: A review. Geol. Carpathica 2017, 68, 57-67. [CrossRef]

36. Giannandrea, P.; Marino, M.; Romeo, M.; Schiattarella, M. Pliocene to Quaternary evolution of the Ofanto Basin in southern Italy: An approach based on the unconformity-bounded stratigraphic units. Ital. J. Geosci. 2013, 133, 27-44. [CrossRef]

37. Labella, R.; Capolongo, D.; Giannandrea, P.; Giano, S.I.; Schiattarella, M. Morphometric analysis of fluvial network and age constraints of terraced surfaces of the Ofanto basin, Southern Italy. Rend. Lincei 2014, 25, 253-263. [CrossRef]

38. Piccarreta, M.; Pasini, A.; Capolongo, D.; Lazzari, M. Changes in daily precipitation extremes in the Mediterranean from 1951 to 2010: The Basilicata region, southern Italy. Int. J. Climatol. 2013, 33, 3229-3248. [CrossRef]

39. Büttner, G. CORINE land cover and land cover change products. In Remote Sensing and Digital Image Processing; Manakos, I., Braun, M., Eds.; Springer: Dordrecht, The Netherlands, 2014.

40. Ramirez, J.A.; Zischg, A.P.; Schürmann, S.; Zimmermann, M.; Weingartner, R.; Coulthard, T.; Keiler, M. Modeling the geomorphic response to early river engineering works using CAESAR-Lisflood. Anthropocene 2020, 32, 100266. [CrossRef]

41. Coulthard, T.J.; Neal, J.C.; Bates, P.D.; Ramirez, J.; de Almeida, G.A.; Hancock, G.R. Integrating the LISFLOOD-FP 2D hydrodynamic model with the CAESAR model: Implications for modelling landscape evolution. Earth Surf. Process. Landf. 2013, 38, 1897-1906. [CrossRef]

42. Coulthard, T.J.; van de Wiel, M.J. Climate, tectonics or morphology: What signals can we see in drainage basin sediment yields? Earth Surf. Dyn. 2013, 1, 13-27. [CrossRef]

43. Hancock, G.R.; Lowry, J.B.C.; Coulthard, T.J.; Evans, K.G.; Moliere, D.R. A catchment scale evaluation of the SIBERIA and CAESAR landscape evolution models. Earth Surf. Process. Landf. 2010, 35, 863-875. [CrossRef]

44. Skinner, C.J.; Coulthard, T.J.; Schwanghart, W.; Wiel, M.J.; Hancock, G. Global sensitivity analysis of parameter uncertainty in landscape evolution models. Geosci. Model Dev. 2018, 11, 4873-4888. [CrossRef]

45. Einstein, H.A. The Bed-Load Function for Sediment Transportation in Open Channel Flows. Soil Conserv. Serv. 1950, 1026, 1-31.

46. Ding, Y.; Jia, Y.; Sam, S.Y.W. Identification of Manning's Roughness Coefficients in Shallow Water Flows. J. Hydraul. Eng. 2004, 130, 501-510. [CrossRef]

47. Phillips, J.V.; Tadayon, S. Selection of Manning's Roughness Coefficient for Natural and Constructed Vegetated and Non-Vegetated Channels, and Vegetation Maintenance Plan Guidelines for Vegetated Channels in Central Arizona; Report 2006-5108; USGS: Washington, DC, USA, 2006.

48. Aucelli, P.P.; Conforti, M.; Della Seta, M.; Del Monte, M.; D'uva, L.; Rosskopf, C.M.; Vergari, F. Multi-temporal Digital Photogrammetric Analysis for Quantitative Assessment of Soil Erosion Rates in the Landola Catchment of the Upper Orcia Valley (Tuscany, Italy). Land Degrad. Dev. 2016, 27, 1075-1092. [CrossRef]

49. Llena, M.; Vericat, D.; Smith, M.W.; Wheaton, J.M. Geomorphic process signatures reshaping sub-humid Mediterranean badlands: 1. Methodological development based on high-resolution topography. Earth Surf. Process. Landf. 2020, 45, 1335-1346. [CrossRef]

50. Del Monte, M.; Vergari, F.; Brandolini, P.; Capolongo, D.; Cevasco, A.; Ciccacci, S.; Zucca, F. Multi-method evaluation of denudation rates in small mediterranean catchments. In Engineering Geology for Society and Territory_Volume 1: Climate Change and Engineering Geology; Springer: Cham, Switzerland, 2015; pp. 563-567.

51. Gioia, D.; Martino, C.; Schiattarella, M. Long- to short-term denudation rates in the southern Apennines: Geomorphological markers and chronological constraints. Geol. Carpathica 2011, 62, 27-41. [CrossRef] 
52. Piccarreta, M.; Capolongo, D.; Boenzi, F.; Bentivenga, M. Implications of decadal changes in precipitation and land use policy to soil erosion in Basilicata, Italy. Catena 2006, 65, 138-151. [CrossRef]

53. Doyle, M.W.; Stanley, E.H.; Harbor, J.M. Channel adjustments following two dam removals in Wisconsin. Water Resour. Res. 2003, 39, 1011. [CrossRef]

Publisher's Note: MDPI stays neutral with regard to jurisdictional claims in published maps and institutional affiliations.

(C) 2020 by the authors. Licensee MDPI, Basel, Switzerland. This article is an open access article distributed under the terms and conditions of the Creative Commons Attribution (CC BY) license (http://creativecommons.org/licenses/by/4.0/). 